\title{
Integration of Cotton Plant Resistance With Selected Organic Boll Weevil, Anthonomus grandis grandis Boheman (Coleoptera: Curculionidae) Control Tactics
}

\author{
Karolayne Lopes Campos ${ }^{1}$, Tamiris Alves de Araújo ${ }^{2}$, Allan T. Showler ${ }^{3}$, Carlos Eduardo Almeida Luz ${ }^{2}$, \\ Weslley Brandão da Silva ${ }^{1}$, Cícero Célio de Figueiredo ${ }^{1}$, Jorge Braz Torres ${ }^{4} \&$ Cristina Schetino Bastos ${ }^{1}$ \\ ${ }^{1}$ Faculdade de Agronomia e Medicina Veterinária, Universidade de Brasília, Campus Darcy Ribeiro, Brasília, \\ DF, Brazil \\ ${ }^{2}$ Universidade Federal de Viçosa, Departamento de Entomologia, Campus Universitário, Viçosa, MG, Brazil \\ ${ }^{3}$ USDA-ARS KBUSLIRL, Kerrville, TX, USA \\ ${ }^{4}$ DEPA-Entomologia, Universidade Rural do Pernambuco, Recife, PE, Brazil \\ Correspondence: Cristina Schetino Bastos, Instituto Central de Ciências Ala-Sul, Faculdade de Agronomia e \\ Medicina Veterinária, Universidade de Brasília, Campus Darcy Ribeiro, Asa Norte, Brasília, DF, 70910-900, \\ Brazil. Tel: 55-619-9175-3612.E-mail: cschetino@unb.br; cschetino@gmail.com
}

Received: January 27, 2019 Accepted: March 1, $2019 \quad$ Online Published: April 15, 2019

doi:10.5539/jas.v11n5p1 URL: https://doi.org/10.5539/jas.v11n5p1

The researchers were financed by Conselho Nacional de Desenvolvimento Cientifico e Tecnológico (CNPq).

\begin{abstract}
The boll weevil, Anthonomus grandis grandis Boheman (Coleoptera: Curculionidae), is one of the key pests and limiting factors to cotton production in conventional and organic systems. We assessed the use of resistant and susceptible cotton cultivars, a neem-based insecticide (Natuneem), and trapping with an A. grandis grandis aggregation pheromone as possible control tactics. In the first of two growing seasons we evaluated resistance of colored fiber cotton cultivars BRS 200, BRS Rubi, BRS Safira, and BRS Verde, and white fiber cotton BRS Aroeira, against $A$. grandis grandis attack. In the second growing season we assessed three colored cotton cultivars grown in and without close association of BRS Aroeira, and two control tactics: the neem-based pesticide and trapping. Because BRS Aroeira showed resistance against $A$. grandis grandis in the first growing season, it was selected to be planted in close association with more susceptible colored cultivars in the second growing season. Field plots with white and colored cotton cultivars reduced the need to control $A$. grandis grandis using the neem-based pesticide. Control by the neem-based pesticide and by trapping were of comparable value although the traps provided measurable control during early cotton growth stages and the neem-based pesticide provided measurable control during later cotton growth stages.
\end{abstract}

Keywords: azadirachtin, Gossypium hirsutum, grandlure, neem, trapping

\section{Introduction}

During $2018 \approx 22.5$ million tons of cotton, Gossypium hirsutum L., lint was produced in the Northern Hemisphere, constituting $\approx 88 \%$ of annual worldwide production (ICAC, 2018). Less than $1 \%, 107,980$ tons, were grown using organic methods. Brazil is one of the top five cotton-producing countries (STATISTA, 2018). Cotton production increased by 300\% between 1990 and 2012 (Albuquerque et al., 2016), and cotton is among the crops most treated with synthetic pesticides (Pignati et al., 2017). Brazil, however, is not among the largest producers of organic cotton (Textile Exchange, 2017). Regardless, increased organic cotton production is anticipated to reduce heavy reliance on synthetic insecticide use in Brazil's cotton growing areas.

Herbivorous arthropods such as the boll weevil, Anthonomus grandis grandis Boheman (Coleoptera: Curculionidae), pose challenges to achieving economically profitable cotton yields in conventional production systems and the challenges they pose to control efforts hinder wider adoption of organic cotton production. The pest originated in tropical Mesoamerica (southern Mexico and parts of Central America) from which it has dispersed and become established in other regions and countries where it causes significant losses to cotton crops 
(Roehrdanz, 2001; Showler, 2009a; Jeger et al., 2017). Damage inflicted by A. grandis grandis is from feeding on flower buds (also called "squares"), particularly large ones (5.5-8 $\mathrm{mm}$ diam), by chewing through the outer "rind" and inserting its rostrum to consume the reproductive structures within (Showler, 2004, 2005, 2006), and by oviposition in the buds. Unless the cotton crop is planted late, most injury to buds occurs on the middle and upper portions of the cotton plant's canopy (Busoli et al., 2004; Showler, Greenberg, Scott Jr., \& Robinson, 2005). A. grandis grandis-induced injury is identifiable by the presence of small feeding punctures and slightly elevated oviposition punctures. Eggs are usually deposited singly inside a cotton bud; after hatching, larvae feed, pupate, and exit as adults usually after the bud has abscised and fallen to the soil surface (Leigh, Roach, \& Watson, 1996; Showler \& Cantu, 2005; Showler \& Robinson, 2008). Injured buds and bolls that remain attached to the plants often do not open properly, and injury can cause yield reduction by abortion and by decreased fiber quantity and quality (Bastos et al., 2005; Showler, 2006, 2007). Typical losses from boll weevil infestations in Brazil are estimated to be valued at US\$70-US\$130 per ha (Soria, Thomazoni, Tachinardi, \& Degrande, 2013).

Organic cotton growers in Brazil do not have effective alternatives to synthetic pesticides (Nussenbaum \& Lecuona, 2012; Neves et al., 2014; Ribeiro et al., 2015; A. L. A. L. Silva \& C. A. D. Silva, 2015). According to Zehnder et al. (2007) pest management tactics for organic crops include cultural practices, nontransgenic plant resistance, releases of biological control agents, use of organic insecticides, and pheromones. The purpose of this research was to evaluate the suitability of combining resistant cotton cultivars with a botanical insecticide and trapping for managing $A$. grandis grandis infestations.

\section{Method}

\subsection{Experimental Conditions}

Each of the two experiments was conducted at Fazenda Agua Limpa, University of Brasilia, Núcleo Rural da Vargem Bonita, Distrito Federal, Brazil (S 155 $7^{\prime} 2^{\prime \prime}, \mathrm{W} 47^{\circ} 56^{\prime} 2^{\prime \prime}$ ). The location was considered to be amenable to organic crop production because all cultivation there after 2009 did not involve the use of synthetic pesticides and fertilizers. The soil was plowed once, harrowed twice, and furrows were formed with $0.9 \mathrm{~m}$ row spacing using a three row mould board plough coupled to a tractor. Twenty tons of cattle and sheep manure (mixed) per ha was manually applied with $1,750 \mathrm{~kg}$ of natural phosphate (Yoorin, Poços de Caldas, MG, Brazil), comprised of $18 \% \mathrm{P}_{2} \mathrm{O}_{5}, 18 \% \mathrm{Ca}, 7 \% \mathrm{Mg}$, and $10 \% \mathrm{Si}$. Cotton seeds were manually planted, seven per meter, on the rows and thinned at the seedling stage to five plants per meter. One month after planting, another 20 tons of cattle and sheep manure per ha was applied in the furrows. Irrigation was provided using a sprinkler system every $3 \mathrm{~d}$ whenever rainfall did not occur for $>3 \mathrm{~d}$ during pre-flowering growth stages. Weeds were rogued manually and vertical cotton growth was managed by removing the tops of plants that were too tall (this is standard procedure in Brazil).

\subsection{Cultivar Resistance to A. grandis grandis}

The first experiment involved five treatments comprised of four colored cotton cultivars and one white cultivar. The colored cotton cultivars were BRS 200, beige lint, perennial; BRS Verde, green lint, annual; BRS Rubi, dark brown lint, annual; and BRS Safira, light brown lint, annual (Carvalho, Andrade, \& Silva Filho, 2011), and the white cultivar was BRS Aroeira. None of the cultivars were transgenic. The experimental plots were arranged in a randomized complete block design with three replicates, and the field was surrounded by cultivated brown hemp, Crotalaria juncea L. Each plot was $6.5 \mathrm{~m} \times 8.8 \mathrm{~m}(\mathrm{w} \times 1)$ with six rows of cotton plants. Planting occurred on February 25, 2010.

Fallen cotton fruiting bodies were collected and numbers of feeding and oviposition punctures, and numbers of larvae, pupae, and adults in each were recorded. The percentage of injured fruiting bodies on the ground was calculated by dividing the number of injured fruiting bodies by the number of total fruiting bodies and multiplying by 100 . Sampling fallen fruiting bodies occurred 89, 96, 104, 109, 117, 138, 146, 154, 160, and 174 $\mathrm{d}$ after planting.

At harvest on August 25, 2010, 10 plants in each plot were randomly selected and all of the lint from each plant was collected manually and stored in paper bags. The lint samples were weighed with the seed and again after the lint had been hand plucked from the seeds. Percentage lint was determined by dividing the lint weight by the lint + seed weight and multiplying by 100. Lint yield was extrapolated to obtain yield estimates per ha.

Before statistical analyses, normality of the data sets and homogeneity of variance were determined. Data on $A$. grandis grandis injury and infestation, lint yield, and percentage lint were analyzed using one-way ANOVA with treatments and block effects (SAS, 2002). Percentage data was arcsin-square root-transformed before analysis. Differences were separated $(\mathrm{P}<0.05)$ using Tukey's HSD (SAS, 2002). 


\subsection{Cultivar Resistance, Botanically-Based Insecticides, and Trapping}

Treatments were comprised of 12 combinations of factors: BRS Safira (light-brown, annual), BRS Rubi (dark-brown, annual), and BRS Topazio (beige lint, annual) (Carvalho, Andrade, \& Silva Filho, 2011) grown with and without BRS Aroeira surrounding the plots. Each of two A. grandis grandis control tactics, treatment with a neem-based insecticide (Natuneem, NaturalNeem, Jaguariúna, SP, Brazil) or trapping using grandlure bait placed in an IscaBW trap (Isca Tecnologia, Ijuí, RS, Brazil), were applied to separate plots of each cultivar. Plants without surrounding BRS Aroeira served as experimental controls to compare against plots where the colored cultivars were grown in association with BRS Aroeira. The treatments were arranged in a randomized complete block design and replicated three times.

Planting occurred on December 1, 2010. Each plot was $4.5 \mathrm{~m} \times 5 \mathrm{~m}(\mathrm{w} \times 1)$ with six rows. All six rows were planted with a single cultivar when they were cultivated alone. In the plots where the colored cotton was grown with BRS Aroeira, BRS Aroeira was planted in the first and sixth rows of the plots and in the end $0.5 \mathrm{~m}$ of the remaining four rows, forming a border around the colored cotton cultivar. The plots were continuous (without keeping any distance between them).

Starting on the 77th day after planting, and weekly thereafter, numbers of $A$. grandis grandis infesting the plants and numbers of fruiting bodies (buds and bolls) with evidence of feeding and oviposition were recorded in five randomly-selected plants per plot. Plants evaluated were located in the center of the plots disregarding the first row on each border (right and left sides of plots) and $0.5 \mathrm{~m}$ in the beginning and in end of the remaning rows. Plants considered to be infested had $\geq 1$ injured fruiting body or visible adult $A$. grandis grandis. To obtain the percentage of infested plants, the number of infested plants was divided by the number of plants sampled and multiplied by 100 . The percentage was compared with the economic threshold, $10 \%$ infested plants, used to manage the pest in low-input cotton-growing systems (Almeida \& Silva 1999). Triggered by infestations that exceeded the economic threshold (on average across the four plots), the neem-based insecticide was applied (on the same day that the sampling was conducted) at 99, 105, 126, 133, and $138 \mathrm{~d}$ after planting for BRS Rubi; days 99, 105, 112, 126, 133, and 138 for BRS Safira; and days 126, 133, and 138 for BRS Topazio. The insecticide, Natuneem, was comprised of 3,000 ppm of pure emulsified oil from the neem tree, Azadirachta indica Juss. (Meliaceae), and was tested at rates of $0.5 \%$ (15 ppm a.i.), 1\% (30 ppm a.i.), and 2\% (60 ppm a.i.) diluted in water $(\mathrm{v} / \mathrm{v})$ for the first, second, and third applications, respectively. It was applied using a $20 \mathrm{~L}$ manually-pumped sprayer (Jacto-PJH20, Pompéia, SP, Brazil) with a cone nozzle (Jacto JD 48, Jacto, Pompéia, SP, Brazil). When $>3$ sprays were needed (i.e., on BRS Rubi and BRS Safira), the $2 \%$ concentration was used after the third spray (higher concentrations caused phytotoxicity in preliminary tests). The solution sprayed (water plus insecticide) was adjusted for a final volume of $300 \mathrm{~L}$ per ha. The sprayed plots were sampled $2 \mathrm{~d}$ after being treated in addition to the weekly sampling times.

The IscaBW traps (Isca Tecnologia, Ijuí, RS, Brazil), were each deployed on a wooden pole with the trap at upper canopy height; trap height was adjusted as the plants grew taller. The traps were installed on day 77, one at the center of each plot (in order to trap, mostly, weevils infesting the plots and to avoid attracting and sampling those located in the surroundings), and the attractant pheromone (Grandlure, ISCAlure BW10, Isca Tecnologia, Ijuí, RS, Brazil) was replaced with a new lure when the numbers of collected A. grandis grandis were recorded on days 84, 93, 107, 121, 135, and 149 after planting. The manufacturer of the attractant pheromone recommends, for sampling purpose, replacement every 30 days. However, as the power of attraction is reduced over time and, considering our distinctive goal of trapping weevils, instead of just sampling, our replacement interval was lower.

Data that were not normally distributed and that did not have variance homogeneity were transformed by $\sqrt{\mathrm{x}+0.5}$ before further analyses. Differences in numbers of $A$. grandis grandis infested fruiting bodies, percentages of infested plants, and numbers of adults per plant on each sampling day were detected using three-way ANOVA (SAS, 2002) so that each treatment factor (cultivar $\times$ cultural practice $\times$ control tactic) and their interactions were tested. Tukey's HSD was used for mean separations $(P<0.05)$. Data from each treatment and sampling day were analyzed to detect treatment differences using one-way ANOVA, and means were separated using the Scott-Knott test $(P<0.05)$ (Scott, \& Knott, 1974). Numbers of adult A. grandis grandis observed before and two days after spraying the neem-based insecticide were analyzed for differences using the two-sample $\mathrm{t}$ test (SAS, 2002). 


\section{Results}

\subsection{Cultivar Resistance to A. grandis grandis}

Cotton cultivars altered numbers of $A$. grandis grandis pupae on day $109\left(\mathrm{~F}_{4,8}=4.26 ; P=0.0388\right)$, day $146\left(\mathrm{~F}_{4,8}\right.$ $=4.74, P=0.0029)$, and day $160\left(\mathrm{~F}_{4,8}=4.64, P=0.0313\right)$ and the percentage of fruiting bodies infested on day $138\left(\mathrm{~F}_{4,8}=4.74, P=0.0295\right)$. By day 109 , BRS Verde had $\approx 4.5$-fold more $A$. grandis grandis than BRS Aroeira. On day 146, only BRS 200 had greater numbers of pupae than the other cultivars (Table 1). More pupae were found in BRS 200 fruiting bodies on day 160 compared with the other colored cotton cultivars; BRS Aroeira produced an intermediate number of pupae (Table 1). On days 146 and day 160, however, numbers of $A$. grandis grandis pupae found inside BRS 200 were $91 \%$ and $93 \%$, respectively, greater than numbers of pupae found within BRS Aroeira fruiting structures. About 47.5\% more infested fruiting bodies occurred in BRS 200 than in BRS Verde (Table 1). BRS Verde produced $\approx 3.1$-fold more cotton lint than BRS $200\left(\mathrm{~F}_{4,8}=21.29 ; P=0.0003\right)$, the least productive cultivar. Percentage lint yield, however, was not affected by the cultivars (Figure 1).

\subsection{Cultivar Resistance, Botanically-Based Insecticides, and Trapping}

The cultivars $\times$ cultural practices $\times$ organic control tactics interaction altered numbers of damaged flower buds by day $70\left(\mathrm{~F}_{2,22}=5.11, P=0.0151\right)$ and day $133\left(\mathrm{~F}_{2,22}=3.96, P=0.0338\right)$, and percentages of infested plants by day $70\left(\mathrm{~F}_{2,22}=5.66, \mathrm{P}=0.0104\right)$. The control methods reduced numbers of damaged flower buds $\left(\mathrm{F}_{1,22}=5.72, P\right.$ $=0.0258)$ and percentages of infested plants $\left(\mathrm{F}_{1,22}=5.70, P=0.0260\right)$ on day 77 . Similarly, the control methods affected abundances of adult $A$. grandis grandis $\left(\mathrm{F}_{1,22}=5.68, P=0.0262\right)$ on day 138 . By day 77 , the cultivars altered numbers of damaged flower buds $\left(\mathrm{F}_{1,22}=8.70, P=0.0074\right)$ and percentages of infested plants $\left(\mathrm{F}_{2,22}=\right.$ $6.86, P=0.0048)$.

On day $70,80 \%$ and $100 \%$ fewer damaged flower buds and percentages of infested plants declined by $83.2 \%$ and $100 \%$ in cultivars BRS Safira and BRS Topázio, respectively, compared to BRS Rubi when plants were growing alone and $A$. grandis grandis was controlled by trapping. On day 133, however, 53.1 and $55.1 \%$ fewer flower buds occurred in cultivars BRS Safira and BRS Topázio, respectively, only when grown in association with BRS Aroeira and where the neem-based insecticide was applied (Table 2a). On the same day, only BRS Safira had $56.2 \%$ and $64.1 \%$ fewer damaged flower buds than BRS Rubi and BRS Topázio, respectively, in plots without BRS Aroeira and where the control tactic was the neem-based insecticide (Table 2a). Also, on day 133 the neem-based insecticide application in BRS Safira without BRS Aroeira reduced numbers of damaged flower buds by $74.5 \%$ compared to trapping (Table $2 \mathrm{a}$ ). Association with BRS Aroeira reduced the density of $A$. grandis grandis by $44 \%$ to $100 \%$ compared to cultivars grown without BRS Aroeira (Table $2 b$ ).

The association of BRS Rubi with BRS Aroeira reduced A. grandis grandis numbers by $10 \%$ by day 133 where trapping was the control tactic. On the same day, however, numbers $A$. grandis grandis found on BRS Rubi and BRS Safira associated with BRS Aroeira were $10 \%$ and $20 \%$ greater, respectively, when the insect was managed with the neem-based insecticide. On day 138, the association of BRS Topazio with BRS Aroeira reduced the numbers of $A$. grandis grandis managed with trapping by $40 \%$, while on the same day plots of BRS Safira cultivated in association with BRS Aroeira and managed with the neem-based insecticide had $40 \%$ more $A$. grandis grandis (Table 3).

On day 126, 38.9\% fewer damaged flower buds occurred on BRS Rubi cultivated alone with trapping. The same occurred on day 133 regardless of the control tactic used; the neem-based insecticide and trapping reduced injury to flower buds by $34.7 \%$ and $42.2 \%$, respectively. BRS Safira grown alone with the neem-based insecticide and BRS Topazio grown alone with trapping had $39.1 \%$ and $37.5 \%$, respectively, fewer damaged flower buds by day 133. On day 138, BRS Rubi cultivated alone and managed with the neem-based insecticide had $26.2 \%$ fewer damaged flower buds. The association of BRS Safira with BRS Aroeira and trapping, and BRS Topazio with BRS Aroeira and the neem-based insecticide reduced numbers of damaged flower buds by $50.9 \%$ and $43.6 \%$, respectively, on day 133 . Suppressing A. grandis grandis infestations by trapping and by cultivating BRS Safira and BRS Topazio in close association with BRS Aroeira reduced numbers of damaged flower buds by $50 \%$ and $51.6 \%$, respectively, on day 138 (Table 4).

Association of BRS Rubi with BRS Aroeira and trapping on day 126, BRS Safira treated with neem-based insecticide on day 133, and BRS Topazio managed with trapping on day 138 increased the numbers of damaged bolls by $66.7 \%, 80 \%$ and $28.6 \%$, respectively. Conversely, damaged bolls were reduced by $75 \%, 84.6 \%, 100 \%$ and $66.7 \%$ in BRS Rubi with BRS Aroeira and the neem-based insecticide and trapping on day 133, and in BRS Rubi with BRS Aroeira and the neem-based insecticide and BRS Safira with BRS Aroeira and trapping on day 138, respectively (Table 5). 
BRS Rubi grown alone with the neem-based insecticide applications had 1.5- and 1.8-fold more infested plants on days 112 and 126, respectively, than when growing in association with BRS Aroeira. BRS Topazio grown in association with BRS Aroeira had $40 \%$ and $45.4 \%$ fewer infested plants on day 126 when the neem-based insecticide and trapping, respectively, were used (Table 6).

Trapping A. grandis grandis reduced numbers of damaged fruiting bodies by $60 \%$ and infested plants by $62.5 \%$ by day 77 compared against plants treated with the neem-based insecticide (Figure 2a). By day 138, however, $56.1 \%$ more adults were found on plants where traps were used (Figure 2b). BRS Safira and BRS Topázio had $81.5 \%$ and $63.0 \%$ fewer damaged flower buds and $78.6 \%$ and $64.3 \%$ fewer infested plants, respectively, by day 77 (Figure 2c).

No differences were observed for numbers of trapped A. grandis grandis females regardless of cultivar (and association with BRS Aroeira) on any of the sampling days. Numbers of females varied and were not statistically different $(P>0.05)$ between plots grown in association with BRS Aroeira and plots that did not include BRS Aroeira. Association of BRS Aroeira reduced the need for neem-based insecticide applications in BRS Rubi (Figures 3A-3B); plants grown apart from BRS Aroeira received five sprays of the neem-based insecticide while three were needed in closely associated plots. Differences were not detected for numbers of $A$. grandis grandis adults before and after spraying the neem-based insecticide (Figure 3).

Table 1. Mean $( \pm \mathrm{SE})$ numbers of pupal Anthonomus grandis grandis and percentages of infested fruiting in five cotton cultivars at 109,138,146, and 160 d after planting. 25 May to 18 Aug 2010, Brasília, DF, Brazil

\begin{tabular}{|c|c|c|c|c|c|c|}
\hline \multirow{2}{*}{ Days after planting } & \multirow{2}{*}{ Dependent variable } & \multicolumn{5}{|c|}{ Cultivars } \\
\hline & & Verde & Safira & Rubi & BRS 200 & Aroeira \\
\hline 109 & Pupae & $12.0 \pm 2.9 \mathrm{~A}$ & $8.0 \pm 3.1 \mathrm{AB}$ & $11.3 \pm 4.6 \mathrm{AB}$ & $5.7 \pm 2.9 \mathrm{AB}$ & $2.7 \pm 0.7 \mathrm{~B}$ \\
\hline 138 & $\%$ infested fruiting bodies ${ }^{a}$ & $16.1 \pm 2.3 \mathrm{~B}$ & $17.9 \pm 1.9 \mathrm{~B}$ & $28.6 \pm 5.4 \mathrm{AB}$ & $33.9 \pm 6.9 \mathrm{~A}$ & $23.5 \pm 2.1 \mathrm{AB}$ \\
\hline 146 & Pupae & $1.0 \pm 0.6 \mathrm{~B}$ & $2.7 \pm 0.9 \mathrm{~B}$ & $1.3 \pm 1.3 \mathrm{~B}$ & $11.0 \pm 2.1 \mathrm{~A}$ & $1.0 \pm 0.6 \mathrm{~B}$ \\
\hline 160 & Pupae & $0 \mathrm{~B}$ & $0 \mathrm{~B}$ & $0 \mathrm{~B}$ & $4.3 \pm 2.0 \mathrm{~A}$ & $0.3 \pm 0.3 \mathrm{AB}$ \\
\hline
\end{tabular}

Note. *Means followed by the same letter within the same row are not statistically different $(P<0.05)$, one-way

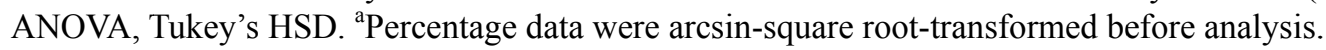

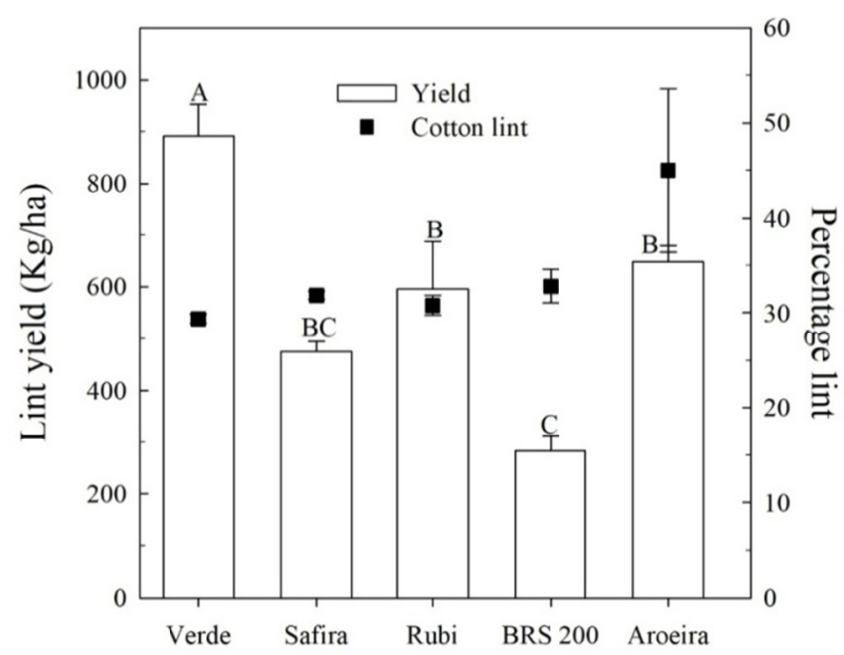

Figure 1. Mean $( \pm \mathrm{SE})$ cotton lint yield $(\mathrm{kg} / \mathrm{ha})$ and percentage lint yield from different cultivars. Bars with the same letters on top are not significantly different $(P<0.05)$, one-way ANOVA, Tukey's HSD; 25 May to 18 Aug 2010, Brasília, DF, Brazil. ${ }^{a}$ Percentage data were arcsin-square root-transformed before analysis 
Table 2a. Mean ( \pm SE) numbers of damaged flower buds and percentages of infested plants in different cotton cultivars surrounded by BRS Aroeira cotton and not surrounded, each subjected to A. grandis grandis trapping or to a neem-based insecticide applications on different sampling days. 9 Feb to 18 Apr 2011, Brasília, DF, Brazil

\begin{tabular}{|c|c|c|c|c|c|}
\hline \multirow{2}{*}{ Variables/Cultivar } & \multirow{2}{*}{ Sampling day ${ }^{a}$} & \multicolumn{2}{|c|}{ With Aroeira } & \multicolumn{2}{|c|}{ Without Aroeira } \\
\hline & & Neem & Trap & Neem & Trap \\
\hline Damaged flower buds ${ }^{b}$ & 70 & & & & \\
\hline Rubi & & $0 \mathrm{Aa}$ & $0 \mathrm{Aa}$ & $0.2 \pm 0.2 \mathrm{Aa}$ & $0.5 \pm 0.2 \mathrm{Aa}$ \\
\hline Safira & & $0.2 \pm 0.2 \mathrm{Aa}$ & $0.1 \pm 0.1 \mathrm{Aa}$ & $0.1 \pm 0.1 \mathrm{Aa}$ & $0.1 \pm 0.1 \mathrm{Ba}$ \\
\hline Topázio & & $0 \mathrm{Aa}$ & $0.1 \pm 0.1 \mathrm{Aa}$ & $0.3 \pm 0.1 \mathrm{Aa}$ & $0 \mathrm{Ba}$ \\
\hline$\%$ infested plants ${ }^{\mathrm{c}}$ & 70 & & & & \\
\hline Rubi & & $0 \mathrm{Aa}$ & $0 \mathrm{Aa}$ & $20.0 \pm 20.0 \mathrm{Aa}$ & $40.0 \pm 11.6 \mathrm{Aa}$ \\
\hline Safira & & $6.7 \pm 6.7 \mathrm{Aa}$ & $6.7 \pm 6.7 \mathrm{Aa}$ & $6.7 \pm 6.7 \mathrm{Aa}$ & $6.7 \pm 6.7 \mathrm{Ba}$ \\
\hline Topázio & & $0 \mathrm{Aa}$ & $13.3 \pm 13.3 \mathrm{Aa}$ & $26.7 \pm 13.3 \mathrm{Aa}$ & $0 \mathrm{Ba}$ \\
\hline Damaged flower buds & 133 & & & & \\
\hline Rubi & & $4.9 \pm 0.7 \mathrm{Aa}$ & $7.1 \pm 2.1 \mathrm{Aa}$ & $3.2 \pm 0.4 \mathrm{Aa}$ & $4.1 \pm 2.0 \mathrm{Aa}$ \\
\hline Safira & & $2.3 \pm 0.5 \mathrm{Ba}$ & $2.7 \pm 0.1 \mathrm{Aa}$ & $1.4 \pm 0.4 \mathrm{Bb}$ & $5.5 \pm 1.2 \mathrm{Aa}$ \\
\hline Topázio & & $2.2 \pm 0.0 \mathrm{Ba}$ & $4.0 \pm 1.3 \mathrm{Aa}$ & $3.9 \pm 0.6 \mathrm{Aa}$ & $2.5 \pm 0.7 \mathrm{Aa}$ \\
\hline
\end{tabular}

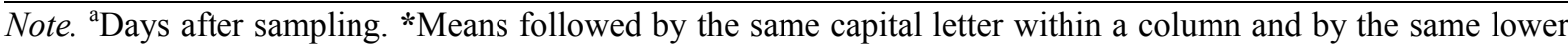
case letter within a row are not statistically different $(P<0.05)$, three-way ANOVA, Tukey's HSD. ${ }^{b}$ Data transformed to $\sqrt{\mathrm{x}+0.5}$; 'Percentage data were arcsin-square root-transformed before analysis.

Table $2 \mathrm{~b}$. Mean $( \pm \mathrm{SE})$ numbers of damaged flower buds and percentages of infested plants in different cotton cultivars surrounded by BRS Aroeira cotton and not surrounded, each subjected to A. grandis grandis trapping or to a neem-based insecticide applications on different sampling days. 9 Feb to 18 Apr 2011, Brasília, DF, Brazil

\begin{tabular}{|c|c|c|c|c|c|}
\hline \multirow{2}{*}{ Variables/Cultivar } & \multirow{2}{*}{ Sampling day ${ }^{\mathrm{a}}$} & \multicolumn{2}{|c|}{ Neem } & \multicolumn{2}{|c|}{ trap } \\
\hline & & With Aroeira & Without Aroeira & With Aroeira & Without Aroeira \\
\hline Damaged buds ${ }^{\mathrm{b}}$ & 70 & & & & \\
\hline Rubi & & $0 \mathrm{a}$ & $0.2 \pm 0.2 \mathrm{a}$ & $0 \mathrm{~b}$ & $0.5 \pm 0.2 \mathrm{a}$ \\
\hline Safira & & $0.2 \pm 0.2 \mathrm{a}$ & $0.1 \pm 0.1 \mathrm{a}$ & $0.1 \pm 0.1 \mathrm{a}$ & $0.1 \pm 0.1 \mathrm{a}$ \\
\hline Topázio & & $0 \mathrm{a}$ & $0.3 \pm 0.1 \mathrm{a}$ & $0.1 \pm 0.1 \mathrm{a}$ & $0 \mathrm{a}$ \\
\hline$\%$ of infested plants & 70 & & & & \\
\hline Rubi & & $0 \mathrm{a}$ & $20.0 \pm 20.0 \mathrm{a}$ & $0 \mathrm{~b}$ & $40.0 \pm 11.6 \mathrm{a}$ \\
\hline Safira & & $6.7 \pm 6.7 \mathrm{a}$ & $6.7 \pm 6.7 \mathrm{a}$ & $6.7 \pm 6.7 \mathrm{a}$ & $6.7 \pm 6.7 \mathrm{a}$ \\
\hline Topázio & & $0 \mathrm{a}$ & $26.7 \pm 13.3 \mathrm{a}$ & $13.3 \pm 13.3 \mathrm{a}$ & $0 \mathrm{a}$ \\
\hline Damaged buds & 133 & & & & \\
\hline Rubi & & $4.9 \pm 0.7 \mathrm{a}$ & $3.2 \pm 0.4 \mathrm{a}$ & $7.1 \pm 2.1 \mathrm{a}$ & $4.1 \pm 2.0 \mathrm{a}$ \\
\hline Safira & & $2.3 \pm 0.5 \mathrm{a}$ & $1.4 \pm 0.4 \mathrm{a}$ & $2.7 \pm 0.1 \mathrm{a}$ & $5.5 \pm 1.2 \mathrm{a}$ \\
\hline Topázio & & $2.2 \pm 0.0 \mathrm{~b}$ & $3.9 \pm 0.6 \mathrm{a}$ & $4.0 \pm 1.3 \mathrm{a}$ & $2.5 \pm 0.7 \mathrm{a}$ \\
\hline
\end{tabular}

Note. ${ }^{a}$ Days after sampling. *Means followed by the same lower case letter within a row are not statistically different $(P<0.05)$, three-way ANOVA, Tukey's HSD. ${ }^{\mathrm{b}}$ Data transformed to $\sqrt{\mathrm{x}+0.5}$. ${ }^{\mathrm{c}}$ Percentage data were arcsin-square root-transformed before analysis. 

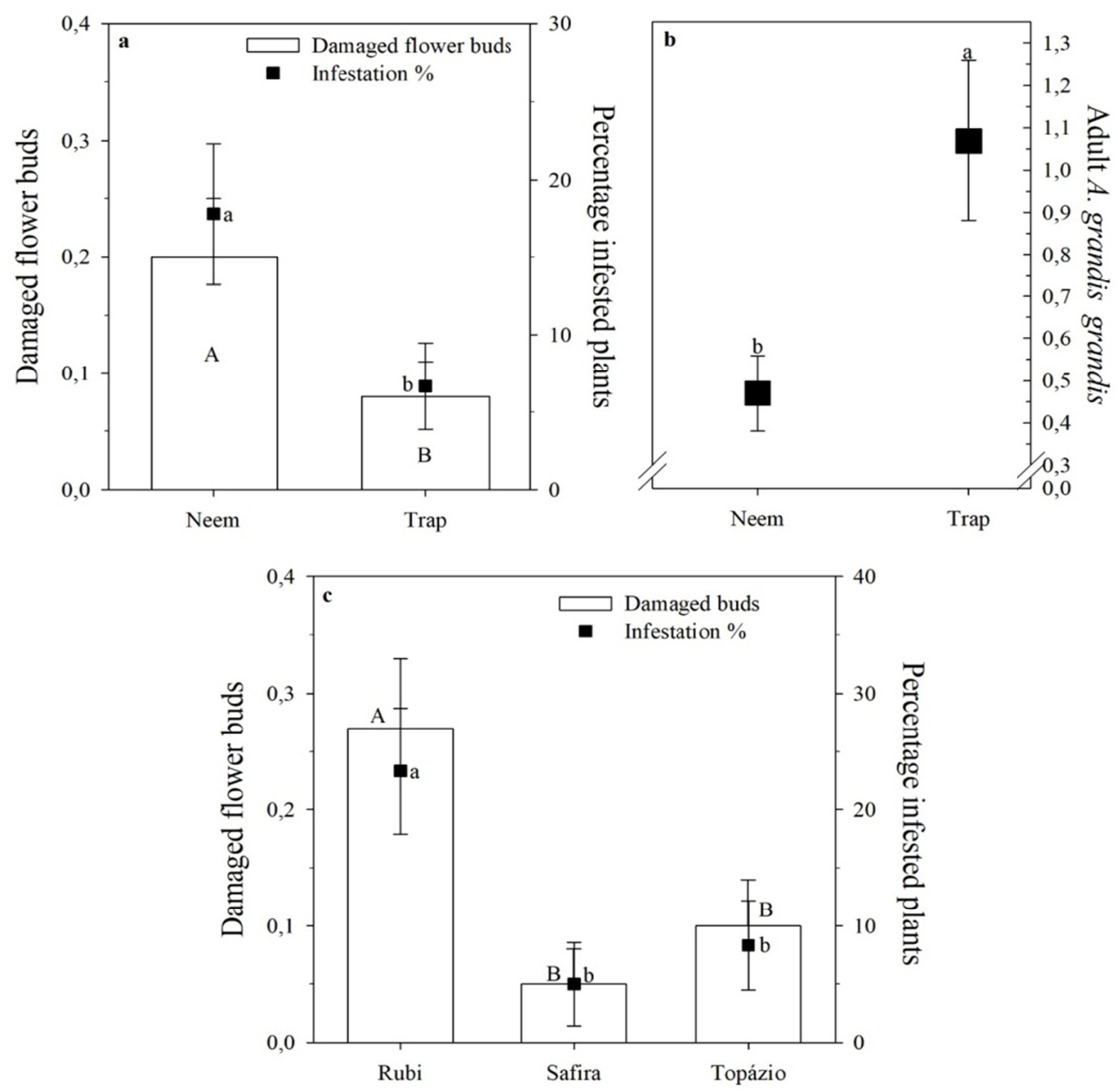

Figure 2. Mean $( \pm \mathrm{SE})$ numbers of a) Anthonomus grandis grandis-damaged flower buds and percentage of infested plants on day 77 (after planting) in cotton plots that were treated with a neem-based insecticide and in

plots where trapping was conducted, b) adult $A$. grandis grandis on the plants on day 138 in neem-based insecticide treated plots and where trapping was conducted, and c) damaged flower buds and percentage infested plants on day 77 in the three cultivars; the same upper case letters over the bars and the same lower case letters over the black squares indicate that the means were not significantly different $(P<0.05)$, three-way ANOVA,

Tukey's HSD; 9 Feb to 18 Apr 2011, Brasília, DF, Brazil. *Percentage infested plants transformed using arcsin-square root-transformation before analysis. 

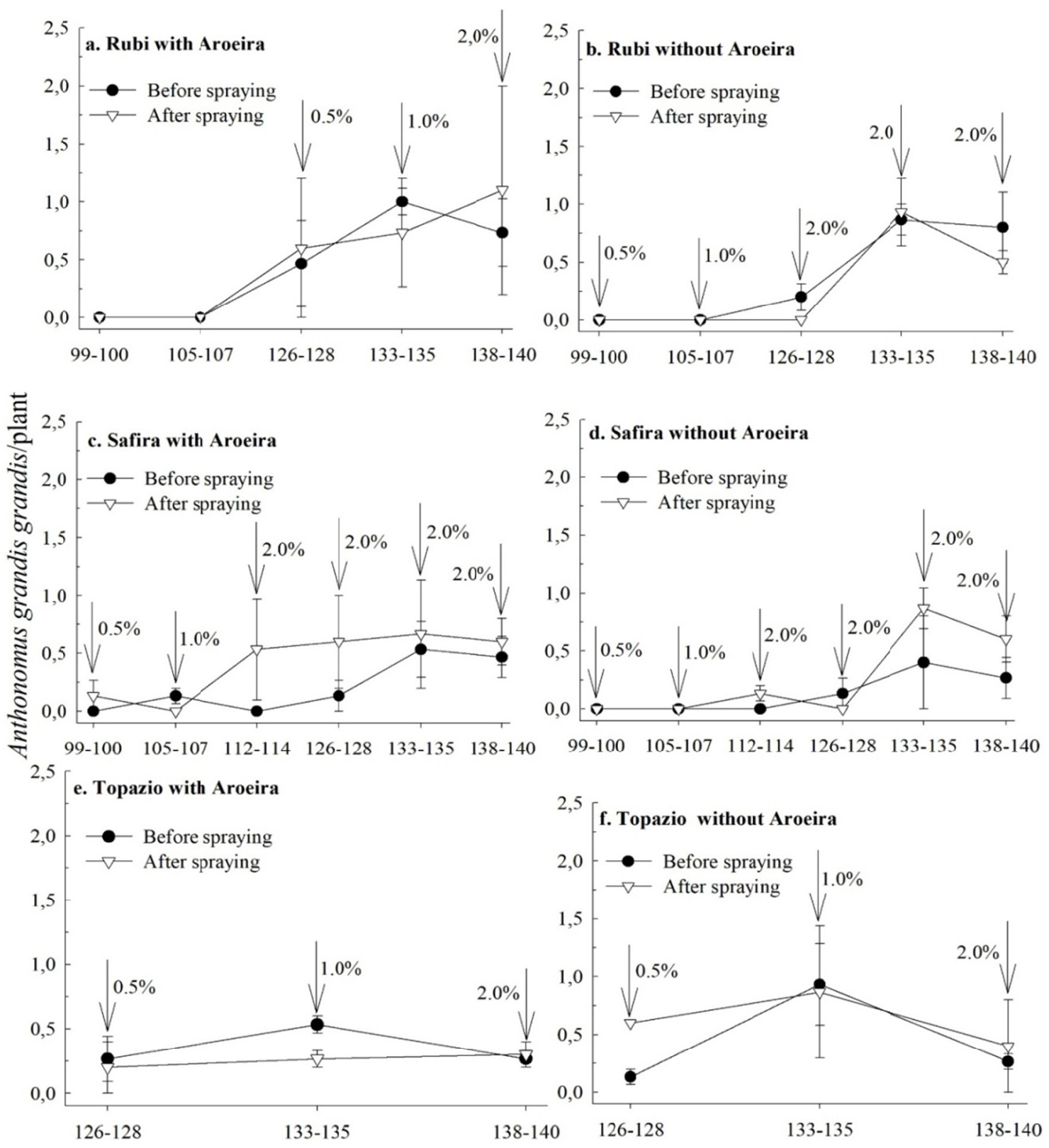

Days After Planting

Figure 3. Mean $( \pm \mathrm{SE})$ numbers of Anthonomus grandis grandis adults per plant in different cultivars surrounded (a, c and e), or not surrounded (b, d and f), by BRS Aroeira on different sampling dates.*Arrows show when the sprays with neem-based insecticide occurred and the number close to them represent the concentrations used (\%v/v). 10 Mar to 20 Apr 2011, Brasília, DF, Brazil 
Table 3. Mean numbers $( \pm \mathrm{SE})$ adult $A$. grandis grandis in different treatments and sampling days (days after planting); five plants were sampled in each of three replicates. 9 Feb to 18 Apr 2011, Brasília, DF, Brazil

\begin{tabular}{|c|c|c|c|c|c|c|c|c|}
\hline \multirow{2}{*}{$\begin{array}{l}\text { Variable/Treatments } \\
\text { Adult } A \text {. grandis grandis }{ }^{\mathrm{a}}\end{array}$} & \multicolumn{8}{|c|}{ Days after planting } \\
\hline & 70 & 77 & 99 & 105 & 112 & 126 & 133 & 138 \\
\hline Rubi+Neem+Aro & $0 \mathrm{c}$ & $0 \mathrm{c}$ & $0 \mathrm{c}$ & $0.1 \pm 0.1 \mathrm{c}$ & $0 \mathrm{c}$ & $0.5 \pm 0.4 \mathrm{c}$ & $1.0 \pm 0.1 \mathrm{a}$ & $0.7 \pm 0.3 \mathrm{~b}$ \\
\hline Rubi+Neem & $0 \mathrm{c}$ & $0 \mathrm{c}$ & $0 \mathrm{c}$ & $0 \mathrm{c}$ & $0 \mathrm{c}$ & $0.2 \pm 0.1 \mathrm{c}$ & $0.9 \pm 0.1 \mathrm{~b}$ & $0.8 \pm 0.3 \mathrm{~b}$ \\
\hline Rubi+Trap+Aro & $0.1 \pm 0.1 \mathrm{c}$ & $0 \mathrm{c}$ & $0 \mathrm{c}$ & $0.1 \pm 0.1 \mathrm{c}$ & $0 \mathrm{c}$ & $0.3 \pm 0.2 \mathrm{c}$ & $1.0 \pm 0.5 \mathrm{~b}$ & $1.7 \pm 0.9 \mathrm{a}$ \\
\hline Rubi+Trap & $0 \mathrm{c}$ & $0.1 \pm 0.1 \mathrm{c}$ & $0.1 \pm 0.1 \mathrm{c}$ & $0 \mathrm{c}$ & $0 \mathrm{c}$ & $0.2 \pm 0.1 \mathrm{c}$ & $1.1 \pm 0.6 \mathrm{a}$ & $1.6 \pm 0.6 \mathrm{a}$ \\
\hline Safira + Neem + Aro & $0 \mathrm{c}$ & $0 \mathrm{c}$ & $0 \mathrm{c}$ & $0.1 \pm 0.1 \mathrm{c}$ & $0 \mathrm{c}$ & $0.1 \pm 0.1 \mathrm{c}$ & $0.5 \pm 0.2 \mathrm{~b}$ & $0.5 \pm 0.2 \mathrm{~b}$ \\
\hline Safira+Neem & $0 \mathrm{c}$ & $0 \mathrm{c}$ & $0 \mathrm{c}$ & $0 \mathrm{c}$ & $0 \mathrm{c}$ & $0.1 \pm 0.1 \mathrm{c}$ & $0.4 \pm 0.4 \mathrm{c}$ & $0.3 \pm 0.2 \mathrm{c}$ \\
\hline Safira+Trap + Aro & $0 \mathrm{c}$ & $0 \mathrm{c}$ & $0 \mathrm{c}$ & $0.1 \pm 0.1 \mathrm{c}$ & $0.1 \pm 0.1 \mathrm{c}$ & $0.1 \pm 0.1 \mathrm{c}$ & $1.1 \pm 0.3 \mathrm{a}$ & $0.8 \pm 0.2 \mathrm{~b}$ \\
\hline Safira+Trap & $0 \mathrm{c}$ & $0 \mathrm{c}$ & $0 \mathrm{c}$ & $0.2 \pm 0.2 \mathrm{c}$ & $0 \mathrm{c}$ & $0.4 \pm 0.3 \mathrm{c}$ & $1.5 \pm 0.6 \mathrm{a}$ & $0.7 \pm 0.1 \mathrm{~b}$ \\
\hline Topazio + Neem + Aro & $0 \mathrm{c}$ & $0 \mathrm{c}$ & $0 \mathrm{c}$ & $0 \mathrm{c}$ & $0 \mathrm{c}$ & $0.3 \pm 0.2 \mathrm{c}$ & $0.5 \pm 0.1 \mathrm{~b}$ & $0.3 \pm 0.1 \mathrm{c}$ \\
\hline Topazio+Neem & $0 \mathrm{c}$ & $0.1 \pm 0.1 \mathrm{c}$ & $0 \mathrm{c}$ & $0.1 \pm 0.1 \mathrm{c}$ & $0 \mathrm{c}$ & $0.1 \pm 0.1 \mathrm{c}$ & $0.9 \pm 0.4 \mathrm{~b}$ & $0.3 \pm 0.1 \mathrm{c}$ \\
\hline Topazio+Trap+Aro & $0.1 \pm 0.1 \mathrm{c}$ & $0 \mathrm{c}$ & $0 \mathrm{c}$ & $0.1 \pm 0.1 \mathrm{c}$ & $0 \mathrm{c}$ & $0.3 \pm 0.1 \mathrm{c}$ & $0.7 \pm 0.1 \mathrm{~b}$ & $0.6 \pm 0.1 \mathrm{~b}$ \\
\hline Topazio+Trap & $0 \mathrm{c}$ & $0 \mathrm{c}$ & $0 \mathrm{c}$ & $0.1 \pm 0.1 \mathrm{c}$ & $0 \mathrm{c}$ & $0.1 \pm 0.1 \mathrm{c}$ & $0.6 \pm 0.2 \mathrm{~b}$ & $1.0 \pm 0.2 \mathrm{a}$ \\
\hline Statistics & \multicolumn{8}{|c|}{$\mathrm{F}_{95,190}=4.93 ; P<0.0001$} \\
\hline
\end{tabular}

Note. ANOVA (analysis of variance); SE (standard error); Aro, BRS Aroeira. *Means followed by the same lower case letter within a row are not statistically different $(P<0.05)$, one-way ANOVA, Scott-Knott test. ${ }^{a}$ Data transformed to $\sqrt{\mathrm{x}+0.5}$.

Table 4. Mean numbers $( \pm \mathrm{SE})$ of damaged flower buds by $A$. grandis grandis in different treatments and sampling days (days after planting); five plants were sampled in each of three replicates. 9 Feb to 18 Apr 2011, Brasília, DF, Brazil

\begin{tabular}{lllllllll}
\hline Variable/Treatments & \multicolumn{7}{c}{ Days after planting } \\
\hline Damaged flower buds $^{\mathrm{a}}$ & 70 & 77 & 99 & 105 & 112 & 126 & 133 & 138 \\
\hline Rubi+Neem+Aro & $0 \mathrm{~d}$ & $0.3 \pm 0.2 \mathrm{~d}$ & $0.5 \pm 0.3 \mathrm{~d}$ & $0.9 \pm 0.3 \mathrm{~d}$ & $1.0 \pm 0.5 \mathrm{~d}$ & $1.2 \pm 0.3 \mathrm{~d}$ & $4.9 \pm 0.7 \mathrm{~b}$ & $4.2 \pm 0.6 \mathrm{~b}$ \\
Rubi+Neem & $0.2 \pm 0.2 \mathrm{~d}$ & $0.4 \pm 0 \mathrm{~d}$ & $0.2 \pm 0.1 \mathrm{~d}$ & $0.3 \pm 0.2 \mathrm{~d}$ & $0.7 \pm 0.5 \mathrm{~d}$ & $0.8 \pm 0.5 \mathrm{~d}$ & $3.2 \pm 0.4 \mathrm{c}$ & $3.1 \pm 1.1 \mathrm{c}$ \\
Rubi+Trap+Aro & $0 \mathrm{~d}$ & $0.2 \pm 0.1 \mathrm{~d}$ & $0.3 \pm 0.2 \mathrm{~d}$ & $1.0 \pm 0.5 \mathrm{~d}$ & $0.5 \pm 0.2 \mathrm{~d}$ & $1.8 \pm 0.5 \mathrm{c}$ & $7.1 \pm 2.1 \mathrm{a}$ & $4.0 \pm 0.9 \mathrm{~b}$ \\
Rubi+Trap & $0.5 \pm 0.2 \mathrm{~d}$ & $0.1 \pm 0.1 \mathrm{~d}$ & $1.1 \pm 1.0 \mathrm{~d}$ & $0.3 \pm 0.1 \mathrm{~d}$ & $0.7 \pm 0.2 \mathrm{~d}$ & $1.1 \pm 0.4 \mathrm{~d}$ & $4.1 \pm 2.0 \mathrm{~b}$ & $5.1 \pm 1.8 \mathrm{~b}$ \\
Safira+Neem+Aro & $0.2 \pm 0.2 \mathrm{~d}$ & $0.1 \pm 0.1 \mathrm{~d}$ & $0.7 \pm 0.5 \mathrm{~d}$ & $1.3 \pm 0.7 \mathrm{~d}$ & $0.2 \pm 0.2 \mathrm{~d}$ & $0.7 \pm 0.4 \mathrm{~d}$ & $2.3 \pm 0.5 \mathrm{c}$ & $2.9 \pm 1.7 \mathrm{c}$ \\
Safira+Neem & $0.1 \pm 0.1 \mathrm{~d}$ & $0.1 \pm 0.1 \mathrm{~d}$ & $0.2 \pm 0.1 \mathrm{~d}$ & $0.1 \pm 0.1 \mathrm{~d}$ & $0.3 \pm 0.2 \mathrm{~d}$ & $0.3 \pm 0.1 \mathrm{~d}$ & $1.4 \pm 0.4 \mathrm{~d}$ & $2.0 \pm 0.8 \mathrm{c}$ \\
Safira+Trap+Aro & $0.1 \pm 0.1 \mathrm{~d}$ & $0 \mathrm{~d}$ & $0.2 \pm 0 \mathrm{~d}$ & $0.5 \pm 0.2 \mathrm{~d}$ & $0.5 \pm 0.4 \mathrm{~d}$ & $0.3 \pm 0.1 \mathrm{~d}$ & $2.7 \pm 0.1 \mathrm{c}$ & $3.3 \pm 0.6 \mathrm{c}$ \\
Safira+Trap & $0.1 \pm 0.1 \mathrm{~d}$ & $0 \mathrm{~d}$ & $0.7 \pm 0.4 \mathrm{~d}$ & $0.6 \pm 0.5 \mathrm{~d}$ & $0.6 \pm 0.4 \mathrm{~d}$ & $1.1 \pm 0.5 \mathrm{~d}$ & $5.5 \pm 1.2 \mathrm{a}$ & $6.6 \pm 0.5 \mathrm{a}$ \\
Topazio+Neem+Aro & $0 \mathrm{~d}$ & $0.1 \pm 0.1 \mathrm{~d}$ & $0.3 \pm 0.2 \mathrm{~d}$ & $0.3 \pm 0.1 \mathrm{~d}$ & $0.6 \pm 0.5 \mathrm{~d}$ & $0.8 \pm 0.5 \mathrm{~d}$ & $2.2 \pm 0 \mathrm{c}$ & $2.7 \pm 1.0 \mathrm{c}$ \\
Topazio+Neem & $0.3 \pm 0.1 \mathrm{~d}$ & $0.1 \pm 0.1 \mathrm{~d}$ & $0.1 \pm 0.1 \mathrm{~d}$ & $0.3 \pm 0.2 \mathrm{~d}$ & $0.3 \pm 0.2 \mathrm{~d}$ & $0.8 \pm 0.4 \mathrm{~d}$ & $3.9 \pm 0.6 \mathrm{~b}$ & $2.8 \pm 1.3 \mathrm{c}$ \\
Topazio+Trap+Aro & $0.1 \pm 0.1 \mathrm{~d}$ & $0.1 \pm 0.1 \mathrm{~d}$ & $0.6 \pm 0.3 \mathrm{~d}$ & $0.3 \pm 0.2 \mathrm{~d}$ & $0.2 \pm 0.1 \mathrm{~d}$ & $0.7 \pm 0.2 \mathrm{~d}$ & $4.0 \pm 1.3 \mathrm{~b}$ & $1.5 \pm 0.2 \mathrm{~d}$ \\
Topazio+Trap & $0 \mathrm{~d}$ & $0 \mathrm{~d}$ & $0.2 \pm 0 \mathrm{~d}$ & $0.6 \pm 0.3 \mathrm{~d}$ & $0.3 \pm 0.2 \mathrm{~d}$ & $1.7 \pm 0.8 \mathrm{~d}$ & $2.5 \pm 0.7 \mathrm{c}$ & $3.1 \pm 0.2 \mathrm{c}$ \\
- Statistics & $\mathrm{F}_{95,190}=8.39 ; P<0.0001$ & & & & & \\
\hline
\end{tabular}

Note. ANOVA (analysis of variance); SE (standard error). Aro, BRS Aroeira. *Means followed by the same lower case letter within a row are not statistically different $(P<0.05)$, one-way ANOVA, Scott-Knott test. ${ }^{a}$ Data transformed to $\sqrt{\mathrm{x}+0.5}$. 
Table 5. Mean numbers ( $\pm \mathrm{SE})$ of damaged bolls by $A$. grandis grandis in different treatments and sampling days (days after planting); five plants were sampled in each of three replicates. 9 Feb to 18 Apr 2011, Brasília, DF, Brazil

\begin{tabular}{|c|c|c|c|c|c|}
\hline Variable & & & ays after $p$ & & \\
\hline Damaged bolls ${ }^{\mathrm{a}}$ & 105 & 112 & 126 & 133 & 138 \\
\hline Rubi+Neem+Aro & $0.1 \pm 0.1 \mathrm{c}$ & $0 \mathrm{c}$ & $0.2 \pm 0.2 \mathrm{c}$ & $0.1 \pm 0.1 \mathrm{c}$ & $0 \mathrm{c}$ \\
\hline Rubi+Neem & $0.1 \pm 0.1 \mathrm{c}$ & $0.1 \pm 0.1 \mathrm{c}$ & $0.1 \pm 0.1 \mathrm{c}$ & $0.4 \pm 0.1 \mathrm{~b}$ & $1.1 \pm 0.4 \mathrm{a}$ \\
\hline Rubi+Trap+Aro & $0 \mathrm{c}$ & $0.1 \pm 0.1 \mathrm{c}$ & $0.3 \pm 0.2 \mathrm{~b}$ & $0.2 \pm 0 \mathrm{c}$ & $1.0 \pm 0.3 \mathrm{a}$ \\
\hline Rubi+Trap & $0.1 \pm 0.1 \mathrm{c}$ & $0.1 \pm 0.1 \mathrm{c}$ & $0.1 \pm 0.1 \mathrm{c}$ & $1.3 \pm 0.9 \mathrm{a}$ & $0.7 \pm 0.4 \mathrm{a}$ \\
\hline Safira + Neem + Aro & $0 \mathrm{c}$ & $0.1 \pm 0.1 \mathrm{c}$ & $0.1 \pm 0.1 \mathrm{c}$ & $0.5 \pm 0.2 \mathrm{~b}$ & $0.4 \pm 0.2 \mathrm{~b}$ \\
\hline Safira+Neem & $0 \mathrm{c}$ & $0 \mathrm{c}$ & $0.1 \pm 0.1 \mathrm{c}$ & $0.1 \pm 0.1 \mathrm{c}$ & $0.6 \pm 0.3 b$ \\
\hline Safira + Trap + Aro & $0 \mathrm{c}$ & $0.1 \pm 0.1 \mathrm{c}$ & $0.1 \pm 0.1 \mathrm{c}$ & $0.2 \pm 0.1 \mathrm{c}$ & $0.3 \pm 0.2 \mathrm{~b}$ \\
\hline Safira+Trap & $0 \mathrm{c}$ & $0 \mathrm{c}$ & $0.2 \pm 0.2 \mathrm{c}$ & $0.3 \pm 0.2 \mathrm{c}$ & $0.9 \pm 0.4 \mathrm{a}$ \\
\hline Topazio+Neem+Aro & $0 \mathrm{c}$ & $0.1 \pm 0.1 \mathrm{c}$ & $0.1 \pm 0.1 \mathrm{c}$ & $0.3 \pm 0.1 \mathrm{~b}$ & $0.6 \pm 0.4 \mathrm{~b}$ \\
\hline Topazio+Neem & $0 \mathrm{c}$ & $0 \mathrm{c}$ & $0.2 \pm 0.2 \mathrm{c}$ & $0.3 \pm 0.1 \mathrm{~b}$ & $0.6 \pm 0.3 \mathrm{~b}$ \\
\hline Topazio+Trap+Aro & $0 \mathrm{c}$ & $0 \mathrm{c}$ & $0.1 \pm 0.1 \mathrm{c}$ & $0.5 \pm 0.3 \mathrm{~b}$ & $0.7 \pm 0.1 \mathrm{a}$ \\
\hline Topazio+Trap & $0 \mathrm{c}$ & $0.1 \pm 0.1 \mathrm{c}$ & $0.1 \pm 0.1 \mathrm{c}$ & $0.4 \pm 0.2 \mathrm{~b}$ & $0.5 \pm 0.1 \mathrm{~b}$ \\
\hline
\end{tabular}

Note. ANOVA (analysis of variance); SE (standard error). Aro, BRS Aroeira. *Means followed by the same lower case letter within a row are not statistically different $(P<0.05)$, one-way ANOVA, Scott-Knott test. a Data transformed to $\sqrt{\mathrm{x}+0.5}$. ${ }^{\mathrm{b}}$ No damage was observed on days 70,77 , and 90 .

Table 6. Mean percentage $( \pm \mathrm{SE})$ of infested plants by A. grandis grandis in different treatments and sampling days (days after planting); five plants were sampled in each of three replicates. 9 Feb to 18 Apr 2011, Brasília, DF, Brazil

\begin{tabular}{|c|c|c|c|c|c|c|c|c|}
\hline Variable & & & & Days aft & r planting & & & \\
\hline \%infested plants ${ }^{\mathrm{a}}$ & 70 & 77 & 99 & 105 & 112 & 126 & 133 & 138 \\
\hline Rubi+Neem+Aro & $0 \mathrm{~b}$ & $26.7 \pm 17.6 \mathrm{~b}$ & $33.3 \pm 24.0 \mathrm{~b}$ & $53.3 \pm 13.3 \mathrm{~b}$ & $60.0 \pm 20.0 \mathrm{a}$ & $60.0 \pm 20.0 \mathrm{a}$ & $86.7 \pm 13.3 \mathrm{a}$ & $93.3 \pm 6.7 \mathrm{a}$ \\
\hline Rubi+Neem & $20.0 \pm 20.0 \mathrm{~b}$ & $40.0 \pm 0 \mathrm{~b}$ & $20.0 \pm 11.6 \mathrm{~b}$ & $33.3 \pm 6.7 \mathrm{~b}$ & $40.0 \pm 23.1 \mathrm{~b}$ & $33.3 \pm 13.3 \mathrm{~b}$ & $93.3 \pm 6.7 \mathrm{a}$ & $86.7 \pm 6.7 \mathrm{a}$ \\
\hline Rubi+Trap+Aro & $0 \mathrm{~b}$ & $13.3 \pm 6.7 \mathrm{~b}$ & $26.7 \pm 17.6 \mathrm{~b}$ & $53.3 \pm 13.3 \mathrm{~b}$ & $40.0 \pm 11.6 \mathrm{~b}$ & $86.7 \pm 6.7 \mathrm{a}$ & $86.7 \pm 6.7 \mathrm{a}$ & $86.7 \pm 13.3 \mathrm{a}$ \\
\hline Rubi+Trap & $40.0 \pm 11.6 \mathrm{~b}$ & $13.3 \pm 6.7 b$ & $40.0 \pm 30.6 \mathrm{~b}$ & $26.7 \pm 6.7 \mathrm{~b}$ & $53.3 \pm 17.6 \mathrm{~b}$ & $66.7 \pm 24.0 \mathrm{a}$ & $86.7 \pm 13.3 \mathrm{a}$ & $100.0 \mathrm{a}$ \\
\hline Safira + Neem+Aro & $6.7 \pm 6.7 \mathrm{~b}$ & $13.3 \pm 13.3 \mathrm{~b}$ & $46.7 \pm 26.7 \mathrm{~b}$ & $33.3 \pm 6.7 \mathrm{~b}$ & $20.0 \pm 11.6 \mathrm{~b}$ & $33.3 \pm 24.0 \mathrm{~b}$ & $86.7 \pm 13.3 \mathrm{a}$ & $66.7 \pm 33.3 \mathrm{a}$ \\
\hline Safira + Neem & $6.7 \pm 6.7 \mathrm{~b}$ & $6.7 \pm 6.7 \mathrm{~b}$ & $20.0 \pm 11.6 \mathrm{~b}$ & $13.3 \pm 6.7 \mathrm{~b}$ & $13.3 \pm 6.7 \mathrm{~b}$ & $33.3 \pm 13.3 \mathrm{~b}$ & $66.7 \pm 13.3 \mathrm{a}$ & $73.3 \pm 17.6 \mathrm{a}$ \\
\hline Safira + Trap + Aro & $6.7 \pm 6.7 \mathrm{~b}$ & $0 \mathrm{~b}$ & $20.0 \pm 0 \mathrm{~b}$ & $40.0 \pm 20.0 \mathrm{~b}$ & $40.0 \pm 30.6 \mathrm{~b}$ & $33.3 \pm 6.7 \mathrm{~b}$ & $93.3 \pm 6.7 \mathrm{a}$ & $93.3 \pm 6.7 \mathrm{a}$ \\
\hline Safira+Trap & $6.7 \pm 6.7 \mathrm{~b}$ & $0 \mathrm{~b}$ & $40.0 \pm 23.1 \mathrm{~b}$ & $40.0 \pm 30.6 \mathrm{~b}$ & $33.3 \pm 24.0 \mathrm{~b}$ & $53.3 \pm 13.3 \mathrm{~b}$ & $100 \mathrm{a}$ & $86.7 \pm 13.3 \mathrm{a}$ \\
\hline Topazio+Neem+Aro & $0 \mathrm{~b}$ & $13.3 \pm 6.7 \mathrm{~b}$ & $26.7 \pm 17.6 \mathrm{~b}$ & $20.0 \pm 0 \mathrm{~b}$ & $33.3 \pm 24.0 \mathrm{~b}$ & $40.0 \pm 23.1 \mathrm{~b}$ & $93.3 \pm 6.7 \mathrm{a}$ & $93.3 \pm 6.7 \mathrm{a}$ \\
\hline Topazio+Neem & $26.7 \pm 13.3 \mathrm{~b}$ & $6.7 \pm 6.7 \mathrm{~b}$ & $13.3 \pm 6.7 \mathrm{~b}$ & $26.7 \pm 17.6 \mathrm{~b}$ & $20.0 \pm 11.6 \mathrm{~b}$ & $66.7 \pm 13.3 \mathrm{a}$ & $100.00 \mathrm{a}$ & $86.7 \pm 6.7 \mathrm{a}$ \\
\hline Topazio+Trap+Aro & $13.3 \pm 13.3 \mathrm{~b}$ & $13.3 \pm 13.3 \mathrm{~b}$ & $33.3 \pm 13.3 \mathrm{~b}$ & $20.0 \pm 0 \mathrm{~b}$ & $13.3 \pm 6.7 \mathrm{~b}$ & $40.0 \pm 11.6 \mathrm{~b}$ & $80.0 \pm 11.6 \mathrm{a}$ & $73.3 \pm 6.7 \mathrm{a}$ \\
\hline Topazio+Trap & $0 \mathrm{~b}$ & $0 \mathrm{~b}$ & $20.0 \pm 0 \mathrm{~b}$ & $46.7 \pm 17.6 \mathrm{~b}$ & $26.7 \pm 17.6 \mathrm{~b}$ & $73.3 \pm 26.7 \mathrm{a}$ & $86.7 \pm 6.7 \mathrm{a}$ & $100 \mathrm{a}$ \\
\hline Statistics & - & & & & & & & \\
\hline
\end{tabular}

Note. ANOVA (analysis of variance); SE (standard error). Aro, BRS Aroeira. *Means followed by the same lower case letter within a row are not statistically different $(P<0.05)$, one-way ANOVA, Scott-Knott test. ${ }^{a}$ Data transformed to arcsin-square root.

\section{Discussion}

Colored cotton cultivar BRS Verde and white BRS Aroeira showed limited resistance against $A$. grandis grandis. Studies that included both the purportedly resistant TB 90 and the susceptible BRS Rubi found no preference in terms of $A$. grandis grandis oviposition, suggesting that the pest is able to infest both cultivars (Silva et al., 2015). Further, TB 90 produced larger flower buds and emerged A. grandis grandis adult body weight was greater than in BRS Rubi. In some instances commercial cultivars show a degree of resistance or susceptibility that is related to the size of fruiting structures they produce (Silva et al., 2015) which is important for $A$. grandis grandis development (Showler, 2005). In addition to wild cotton traits such as frego bracts (Jenkins \& Parrot, 
1971), okra leaves (Vidal Neto, Silva, Bleicher, \& Melo, 2005), trichomes, and some allelochemicals (Hagenbucher et al., 2013), the size of cotton fruiting structures affects the extent of a cultivar's susceptibility (Showler, 2005).

Intercropping two differently colored cotton cultivars is not recommended in order to avoid color mixing (Carvalho, 2008). BRS Aroeira was chosen because of its resistance and because white lint can be mixed with colored lints; addition of white fibers alters the color intensity without changing the color (Carvalho, 2008). The combined cultivation of two crops (Schader, Zaller, \& Köpke, 2005; Vaiyapuri, Amanullah, Rajendran, \& Sathyamoorthi, 2010), and more than one cultivar of the same crop (Trenbath, 1993) whereby one is more resistant than the other, can provide some degree of protection to the relatively susceptible crop and cultivar (Trenbath, 1993; Smith \& McSorley, 2000). The reduced pest infestation occurs because cultivars growing in isolation are presumably easier to find than cultivars that have been mixed with other cultivars, and because mixture of cultivars might allow one of them to serve as a trap crop or as a repellent crop (Trenbath, 1993; Smith \& McSorley, 2000).

The second field experiment showed that colored cotton lint cultivars benefit from being grown in close proximity to white BRS Aroeira cotton in terms of reducing A. grandis grandis populations, numbers of damaged flower buds and bolls, and percentages of infested plants, and by decreasing the need for intervention with the neem-based insecticide. We determined that the effect was particularly evident in the most susceptible cultivars such as BRS Rubi and BRS Safira, compared to BRS Topázio. The partial protection we observed might have resulted from the resistant cultivar interfering with cues that would otherwise attract $A$. grandis grandis adults into those plots (Zhang \& Chen, 2015). This has been reported previously when cotton and basil, Ocimum basilicum L., were intercropped, reducing bollworm, Helicoverpa armigera (Hubner), abundance by $50 \%$ (Schader, 2005). Intercropping has also been reported to reduce pest incidence on small grain farms in Africa (Pickett, Woodcock, Midega, \& Khan, 2014), in citrus orchards intercropped with guava, Psidium guajava L., for psyllid control (Yan, Zenga, \& Zhonga, 2015); and where cauliflower, Brassica oleracea var. botrytis L., and leeks, Allium ampeloprasum L., are grown with flowers along the edges to reduce thrips infestations (Eyre, Labanowska-Bury, White, \& Leifert, 2011). Some protectant effects of intercropping and vegetational diversification can also be achieved from the increased incidence of natural enemies (Altieri, Schoonhoven, \& Doll, 1977; Showler \& Reagan, 1991; Showler, 2013) and by trap cropping with other plant species (Vaiyapuri, Amanullah, Rajendran, \& Sathyamoorthi, 2010). Pest suppression is often improved in a vegetationally diversified habitat, including mixed cultivars, because of the prevalence of bottom-up and top-down effects on pest populations and niche-partitioning (Tooker \& Frank, 2012).

The efficacies of trapping with the grandlure-baited trap, and application of the neem-based insecticide, were similar, but the trap provided better control at early cotton growth stages (day 77), while the neem-based insecticide caused more pest repellency at later stages (day 138). The effect of the neem-based insecticide became particularly apparent once the maximum concentration $(2 \% \mathrm{v} / \mathrm{v})$ was applied. Neem-based insecticides can exert different effects on different insects that include repellency, feeding inhibition, growth regulation, molting disturbance, and sterility (Schmutterer, 1990, 1995; Mordue, 2004). Showler et al. (2004) reported that $A$. grandis grandis was repelled from cotton fruiting bodies that had been treated with commercial neem-based insecticides and, in choice assays, feeding and oviposition punctures were less abundant on neem-treated fruiting bodies than on nontreated fruiting bodies. Field applications of neem-based insecticides provided $46 \%$ to $60 \%$ and $62 \%$ to $82 \%$ reductions in feeding and oviposition punctures, respectively, by $24 \mathrm{~h}$; after $72 \mathrm{~h}$, however, treatment differences were no longer apparent (Showler, Greenberg, \& Arnason, 2004).

Neem oil, on which Natuneem is based, sometimes contains more than a dozen bioactive compounds with insecticidal properties, but the major contributor to the observed insecticidal activity is azadirachtin. The relatively low residual efficacy of azadirachtin has the advantage of protecting nontarget arthropods, some of which can be beneficial (Schmutterer 1990, 1995; Zanuncio et al., 2016). A disadvantage of neem-based products is that they might need to be re-applied often because they are degraded by sunlight in $\approx 2.5 \mathrm{~d}$ (Johnson, Dureja, \& Dhingra, 2003) and increased concentrations might be required to achieve suitable levels of control which, particularly where oil carriers are used, can cause phytotoxicity (Kavallieratos et al., 2007). On the other hand, neem-based products are usually compatible with other organic treatments, such as formulations containing entomopathogens Chromobacterium subtsugae and Beauveria bassiana (Rogers, Ownley, Avery, \& Wszelaki, 2017).

Grandlure is more effective at attracting A. grandis grandis early in the cotton growing season than late because fruiting bodies are either not yet present or because they are too small to be of value to the pest (Showler, 2004). As buds develop before flowering, their attractancy and utility to A. grandis grandis development outcompetes 
the single-point source grandlure bait (Showler, 2007) despite increases in weevil populations (Showler, Greenberg, Scott Jr., \& Robinson, 2005; Magalhäes et al., 2012, 2016). Previous studies determined that increasing dosages of grandlure usually captures more weevils (Legget, 1980) and that the combination of the pheromone with some plant volatiles increases trap captures (Magalhäes et al., 2012, 2016). The relatively low late-season numbers of $A$. grandis grandis where colored cotton cultivars are grown with BRS Aroeira is likely because there were fewer susceptible (attractive) cultivar buds in the BRS Aroeira-associated plots (Showler, Greenberg, Scott Jr., \& Robinson, 2005; Neves, Torres, Barros, \& Vivan, 2018). While it is possible to capture large numbers of adult $A$. grandis grandis in grandlure-baited large capacity traps (Showler, 2003), trapping has not been shown to reduce adult $A$. grandis grandis populations in commercial cotton fields (Showler, 2009b).

Organic cultivation of cotton is challenging mostly because of the prevalence of $A$. grandis grandis during stages of the crop when the buds are most attractive and vulnerable (Showler, Greenberg, Scott Jr., \& Robinson, 2005). We found that curative management options available for $A$. grandis grandis control in organic cotton, such as neem-based insecticides and trapping, do not provide sufficient control when used alone. However, the mixture of resistant cultivars with more susceptible cultivars integrated with botanical insecticides and trapping provided better control of $A$. grandis grandis although still not sufficient to keep the pest under economic threshold throughout the entire growing season. On that matter, future work should consider the combination of other cultural, physical and/or mechanical control measures (allowed in organic cultivations) with those exploited in the current work in the management of the pest, since the key for managing pests in organic systems relie, mostly, on integration (Zehnder et al., 2007).

\section{Acknowledgements}

This work was supported in part by the Conselho Nacional de Desenvolvimento Científico e Tecnológico (CNPq) which provided scholarships and fellowships for some of the authors.

\section{Trade Names or Commercial Products}

Mention of trade names or commercial products in this publication is solely for the purpose of providing specific information and does not imply recommendation or endorsement by the U.S. Department of Agriculture. USDA is an equal opportunity provider and employer.

\section{References}

Albuquerque, J. F. R., Kummrow, F., Nogueira, A. J. A., Montagnerd, C. C., \& Umbuzeiro, G. A. (2016). Pesticides in Brazilian freshwaters: A critical review. Environmental Science: Processes \& Impacts, 18, 779-787. https://doi.org/10.1039/C6EM00268D

Almeida, R. P., \& Silva, C. A. D. (1999). Manejo integrado de pragas do algodoeiro. In N. E. M. Beltrão (Ed.), $O$ agronegócio do algodão no Brasil (pp. 753-820). Campina Grande, BR: Embrapa Algodão.

Altieri, M. A., Schoonhoven, A., \& Doll, J. D. (1977). The ecological role of weeds in insect pest management systems: A review illustrated with bean (Phaseolus vulgaris L.) cropping systems. Tropical Pest Management, 23, 195-205.

Bastos, C. S., Pereira, M. J. B., Takizawa, E. K., Ohl, G., \& Aquino, V. R. de. (2005). Bicudo do algodoeiro: Identificação, biologia, amostragem e táticas de controle. Embrapa Algodão, Circular Técnica 79. Campina Grande, PB.

Busoli, A. C., Pereira, F. F., Lopéz, V. A. G., Soares, J. J., Melo, R. de S., \& Almeida, C. A. de. (2004). Preferência alimentar do bicudo-do-algodoeiro por frutos de diferentes cultivares e idades. Pesquisa Agropecuária Brasileira, 39, 101-104. https://doi.org/10.1590/S0100-204X2004000200001

Carvalho, L. P. de, Andrade, F. P., \& Silva Filho, J. L. (2011). Cultivares de algodão colorido no Brasil. Revista Brasileira de Oleaginosas e Fibrosas, 15, 37-44.

Carvalho, L. P. de. (2008). O gênero Gossypium e suas espécies cultivadas e silvestres. In N. E. de M. Beltrão, \& D. M. P. de Azevedo (Eds.), O agronegócio do algodão no Brasil (pp. 253-270). Brasília, BR: Embrapa Informação Tecnológica.

Eyre, M. D., Labanowska-Bury, D., White, R., \& Leifert, C. (2011) Relationships between beneficial invertebrates, field margin vegetation, and thrips damage in organic leek fields in eastern England. Organic Agriculture, 1, 45-54. https://doi.org/10.1007/s13165-010-0004-x 
Hagenbucher, S., Olson, D. M., Ruberson, J. R., Wäckers, F. L., \& Romeis, J. (2013). Mechanisms against arthropod herbivores in cotton and their interactions with natural enemies. Critical Reviews in Plant Sciences, 32, 458-482. https://doi.org/10.1080/07352689.2013.809293

International Cotton Advisory Committee (ICAC). (2018). Global cotton consumption projected to increase in 2017/18. Retrieved from https://www.icac.org/Press-Release/2018-(1)/PR-1-2018-Global-ConsumptionIncreasing

Jeger, M., Bragard, C., Caffier, D., Candresse, T., Chatzivassiliou, E., Dehnen-Schmutz, K., ... Macleod, A. (2017). Pest categorisation of Anthonomus grandis. European Food Safety Authority Journal, 15, 5074. https://doi.org/10.2903/j.efsa.2017.5074

Jenkins, J. N., \& Parrott, W. L. (1971). Effectiveness of frego bract as a boll weevil resistance character in cotton. Crop Science, 11, 739-743. https://doi.org/10.2135/cropsci1971.0011183X001100050041x

Johnson, S., Dureja, P., \& Dhingra, S. (2003). Photostabilizers for azadirachtin-A (a neem-based pesticide). Journal of Environmental Science and Health, Part B, 38, 451-462. https://doi.org/10.1081/PFC-120021665

Kavallieratos, N. G., Athanassiou, C. G., Kontodimas, D. C., Roussos, A. N., Tsoutsa, M. S., \& Anastassopoulou, U. A. (2007). Effect of two azadirachtin formulations against adults of Sitophilus oryzae and Tribolium confusum on different grain commodities. Journal of Food Protection, 70, 1627-1632. https://doi.org/ 10.4315/0362-028X-70.7.1627

Legget, J. E. (1980). Boll weevil: Competitive and non-competitive evaluation of factors affecting pheromone trap efficiency. Environmental Entomology, 9, 416-419. https://doi.org/10.1093/ee/9.4.416

Leigh, T. F., Roach, S. H., \& Watson, T. F. (1996). Biology and ecology of important insect and mite pests of cotton. In E. G., King, J. R., Phillips, \& R. J. Coleman (Eds.), Cotton insects and mites: Characterization and management (3rd ed., pp. 16-86). Memphis: The Cotton Foundation.

Magalhães, D. M., Borges, M., Laumann, R. A., Sujii, E. R., Mayor, P., Caulfield, J. C., ... Blassioli-Moraes, M. C. (2012). Semiochemicals from herbivory induced cotton plants enhance the foraging behaviour of the cotton boll weevil, Anthonomus grandis. Journal of Chemical Ecology, 38, 1528-1538. https://doi.org/ 10.1007/s10886-012-0216-5

Magalhães, D. M., Borges, M., Laumann, R. A., Woodcock, C. M., Pickett, J. A., Birkett, M. A., \& Blassioli-Moraes, M. C. (2016). Influence of two acyclic homoterpenes (Tetranorterpenes) on the foraging behavior of Anthonomus grandis Boh. Journal of Chemical Ecology, 42, 305-313. https://doi.org/10.1007/ s10886-016-0691-1

Mordue, A. (2004). Present concepts of the mode of action of azadirachtin from neem. In K. W. Opender (Ed.), Neem: Today and in the new millennium (pp. 229-242). Dordrecht: Kluwer Academic Publishers. https://doi.org/10.1007/1-4020-2596-3_11

Neves, R. C. S., Colares, F., Torres, J. B., Santos, R. L., \& Bastos, C. S. (2014). Rational practices to manage boll weevils colonization and population growth on family farms in the Semiárido region of Brazil. Insects, 5, 818-831. https://doi.org/10.3390/insects5040818

Neves, R. C. S., Torres, J. B., Barros, E. M., \& Vivan, L. M. (2018). Boll weevil within season and off-season activity monitored using a pheromone-and-glue reusable tube trap. Scientia Agricola, 75, 313-320. https://doi.org/10.1590/1678-992x-2016-0450

Nussenbaum, A. L., \& Lecuona, R. E. (2012). Selection of Beauveria bassiana sensu lato and Metarhizium anisopliae sensu lato isolates as microbial control agents against the boll weevil (Anthonomus grandis) in Argentina. Journal of Invertebrate Pathology, 110, 1-7. https://doi.org/10.1016/j.jip.2012.01.010

Pickett, J. A., Woodcock, C. M., Midega, C., \& Khan, Z. R. (2014). Push-pull farming systems. Current Opinion in Biotechnology, 26, 125-132. https://doi.org/10.1016/j.copbio.2013.12.006

Pignati, W. A., Lima, F. A. N. de S, Lara, S. S. de, Correa, M. L. M., Barbosa, J. R., Leão, L. H. da C., \& Pignatti, M.G. (2017). Spatial distribution of pesticide use in Brazil: A strategy for health surveillance. Ciência \& Saúde Coletiva, 22, 3281-3293. https://doi.org/10.1590/1413-812320172210.17742017

Ribeiro, E. B., Castellani, M. A., Silva, C. A. D., Melo, T. L., Silva, G. S. S., Vale, W. S., \& Santos, A. S. (2015). Métodos de destruição de restos de cultura do algodoeiro e sobrevivência do bicudo. Pesquisa Agropecuária Brasileira, 50, 993-998. https://doi.org/10.1590/S0100-204X2015001100001 
Roehrdanz, R. L. (2001). Genetic differentiation of southeastern boll weevil and thurberia weevil populations of Anthonomus grandis (Coleoptera: Curculionidae) using mitochondrial DNA. Annals of the Entomological Society of America, 94, 928-935. https://doi.org/10.1603/0013-8746(2001)094[0928:GDOSBW]2.0.CO;2

Rogers, M. A., Ownley, B. H., Avery, P. B., \& Wszelaki, A. L. (2017). Toxicity and efficacy of novel biopesticides for organic management of cucumber beetles on Galia muskmelons. Organic Agriculture, 7, 365-377. https://doi.org/10.1007/s13165-016-0161-7

SAS. (2002). The SAS system (Version 9.00). Cary: SAS Institute.

Schader, C., Zaller, J. G., \& Köpke, U. (2005). Cotton-basil intercropping: Effects on pests, yields and economical parameters in an organic field in Fayoum, Egypt. Biological Agriculture \& Horticulture, 23, 59-72. https://doi.org/10.1080/01448765.2005.9755308

Schmutterer, H. (1990). Properties and potential of natural pesticide from the neem tree, Azadirachta indica. Annual Review of Entomology, 35, 271-297. https://doi.org/10.1146/annurev.en.35.010190.001415

Schmutterer, H. (1995). The neem tree Azadirachta indica A. Juss. and other meliaceous plants: Sources of unique natural products for integrated pest management, medicine, industry and other purposes. Weinheim, DE: VCH Publishers. https://doi.org/10.1002/3527603980

Scott, A. J., \& Knott, M. A. (1974). A cluster analysis method for grouping means in the analysis of variance. Biometrics, 30, 507-512. https://doi.org/10.2307/2529204

Showler, A. T. (2003). Effects of routine late season field operations on numbers of boll weevils (Coleoptera: Curculionidae) captured in large capacity pheromone traps. Journal of Economic Entomology, 96, 680-689. https://doi.org/10.1603/0022-0493-96.3.680

Showler, A. T. (2004). Influence of cotton fruit stages as food sources on boll weevil (Coleoptera: Curculionidae) fecundity and oviposition. Journal of Economic Entomology, 97, 1330-1334. https://doi.org/10.1603/00220493-97.4.1330

Showler, A. T. (2006). Boll weevil damage to cotton bolls under standard and proactive spraying. Journal of Economic Entomology, 99, 1251-1257. https://doi.org/10.1603/0022-0493-99.4.1251

Showler, A. T. (2007). Subtropical boll weevil ecology. American Entomologist, 53, 240-249. https://doi.org/ 10.1093/ae/53.4.240

Showler, A. T. (2009a). Roles of host plants in boll weevil range expansion beyond tropical Mesoamerica. American Entomologist, 55, 228-236. https://doi.org/10.1093/ae/55.4.234

Showler, A. T. (2009b). Efficiency of tank-mixing insecticide with defoliant against adult boll weevil (Coleoptera: Curculionidae) populations as determined by late-season field disturbance trapping. Subtropical Plant Science, 60, 58-65.

Showler, A. T. (2013). Beneficial and detrimental interactions between weeds and other pests of sugarcane. In A. Taab (Ed.), Weeds: cultivation, ecological benefits and role in biological diversity (pp. 153-188). New York, USA: Nova.

Showler, A. T., \& Cantú, R. V. (2005). Intervals between boll weevil (Coleoptera: Curculionidae) oviposition and square abscission, and development to adulthood in Lower Rio Grande Valley, Texas, field conditions. Southwestern Entomologist, 30, 161-164.

Showler, A. T., \& Reagan, T. E. (1991). Effects of sugarcane borer, weed, and nematode control strategies in Louisiana sugarcane. Environmental Entomology, 20, 358-370. https://doi.org/10.1093/ee/20.1.358

Showler, A. T., \& Robinson, J. R. C. (2008). Relationships of abscised cotton fruit to boll weevil (Coleoptera: Curculionidae) feeding, oviposition, and development. Journal of Economic Entomology, 101, https://doi.org/10.1093/jee/101.1.68

Showler, A. T., Greenberg, S. M., \& Arnason, J. T. (2004). Deterrent effects of four neem-based formulations on gravid female boll weevil (Coleoptera: Curculionidae) feeding and oviposition on cotton squares. Journal of Economic Entomology, 97, 414-421. https://doi.org/10.1603/0022-0493-97.2.414

Showler, A. T., Greenberg, S. M., Scott Jr., A. W., \& Robinson, J. R. C. (2005). Effects of planting dates on boll weevils (Coleoptera: Curculionidae) and cotton fruit in the subtropics. Journal of Economic Entomology, 98, 796-804. https://doi.org/10.1603/0022-0493-98.3.796 
Showler, A.T. (2005). Relationships of different cotton square sizes to boll weevil (Coleoptera: Curculionidae) feeding and oviposition in field conditions. Journal of Economic Entomology, 98, 572-579. https://doi.org/ 10.1603/0022-0493-98.5.1572

Silva, A. L. A. L., \& Silva, C. A. D. (2015). Concentração eficiente e econômica de caulim para a proteção de algodoeiro contra o bicudo. Pesquisa Agropecuária Brasileira, 50, 763-768. https://doi.org/10.1590/S0100 $-204 X 2015000900004$

Silva, J. B., Silva-Torres, C. S. A., Moraes, M. C., Torres, J. B., Laumann, R. A., \& Borges, M. (2015). Interaction of Anthonomus grandis and cotton genotypes: Biological and behavioral responses. Entomologia Experimentalis et Applicata, 156, 238-253. https://doi.org/10.1111/eea.12326

Smith, H. A., \& McSorley, R. (2000). Intercropping and pest management: A review of major concepts. American Entomologist, 46, 154-161. https://doi.org/10.1093/ae/46.3.154

Soria, M. F., Thomazoni, D., Tachinardi, R., \& Degrande, P. E. (2013). Alerta para o bicudo-do-algodoeiro: breve panorama pré-safra 2012/13 e ações para o combate da praga. Cuiabá, BR: Instituto Mato-Grossense do Algodão.

STATISTA. (2018). Cotton production by country worldwide in 2016/2017. Retrieved from https://www.statista.com/statistics/263055/cotton-production-worldwide-by-top-countries

Textile Exchange. (2017). Organic cotton market report 2017. Washington, USA: Textile Exchange.

Tooker, J. F., \& Frank, S. D. (2012). Genotypically diverse cultivar mixtures for insect pest management and increased crop yields. Journal of Applied Ecology, 49, 974-985. https://doi.org/10.1111/j.1365-2664. 2012.02173.x

Trenbath, B. R. (1993). Intercropping for the management of pests and diseases. Field Crops Research, 34, 381-405. https://doi.org/10.1016/0378-4290(93)90123-5

Vaiyapuri, K., Amanullah, M. M., Rajendran, K., \& Sathyamoorthi, K. (2010). Intercropping unconventional green manures in cotton: An organic approach for multiple benefits: A review. Asian Journal of Plant Sciences, 9, 223-226. https://doi.org/10.3923/ajps.2010.223.226

Vidal Neto, F. C., Silva, F. P., Bleicher, E., \& Melo, F. I. (2005). Mutantes morfológicos de algodoeiro herbáceo como fonte de resistência ao bicudo. Pesquisa Agropecuária Brasileira, 40, 123-128. https://doi.org/10. 1590/S0100-204X2005000200004

Yan, H., Zenga, J., Zhonga, G. (2015). The push-pull strategy for citrus psyllid control. Pest Management Science, 71, 893-896. https://doi.org/10.1002/ps.3915

Zanuncio, J. C., Mourão, S. A., Martínez, L. C., Wilcken, C. F., Ramalho, F. S., Plata-Rueda, A., ... Serrão, J. E. (2016). Toxic effects of the neem oil (Azadirachta indica) formulation on the stink bug predator, Podisus nigrispinus (Heteroptera: Pentatomidae). Sci Rep, 6, 30261. https://doi.org/10.1038/srep30261

Zehnder, G., Gurr, G. M., Kühne, S., Wade, M. R., Wratten, S. D., \& Wyss, E. (2007). Arthropod pest management in organic crops. Annual Review of Entomology, 52, 57-80. https://doi.org/10.1146/annurev. ento.52.110405.091337

Zhang, Z., \& Chen, Z. (2015). Non-host plant essential oil volatiles with potential for a 'push-pull' strategy to control the tea green leafhopper, Empoasca vitis. Entomologia Experimentalis et Applicata, 156, 77-87. https://doi.org/10.1111/eea.12310

\section{Copyrights}

Copyright for this article is retained by the author(s), with first publication rights granted to the journal.

This is an open-access article distributed under the terms and conditions of the Creative Commons Attribution license (http://creativecommons.org/licenses/by/4.0/). 